\title{
Steps for biomodel acquisition through addtive manufacturing for health
}

\author{
Passos para a obtenção de biomodelos em manufatura aditiva para a saúde
}

\author{
Ana Waleska Pessoa BARROS ${ }^{1}$ \\ Érika PORTO' \\ Jefferson Felipe Silva de LIMA² $^{2}$ \\ Nadja Maria da Silva Oliveira BRITO' \\ Renata de Souza Coelho SOARES'
}

\begin{abstract}
The use of rapid prototyping in medical and dental fields consists of three-dimensional models using Computer Aided Design systems and Computer Aided Manufacturing systems. Such systems focus specifically on enhanced 3D visualization tools that provide a precise preoperative planning opportunity through three-dimensional printing, to the professional. The objective of this study was to describe the main steps in the biomodel manufacturing using an Objet 3D printer (CONNEX 350), whose raw material is a light-curing resin. The steps are adopted by researchers from three-dimensional technologies laboratory (LT3D), of the Center for Strategic Technologies in Health (NUTES), from the State University of Paraiba (UEPB), Brazil. It begins with the acquisition of tomographic images that are processed through specific software and exported to the digital Stereo lithography (STL) format. The additive manufacturing technique is Stereo lithography, which consists in the construction of biomodel by photopolymerization of a liquid epoxy resin using ultraviolet radiation. The biomodel that comes from this process was brought to a pressurizing machine to remove the resin support, washing it with water jets. After this step, this biomodel was sent to the health professional in charge. The use of biomodels constitutes a major breakthrough in the area of Dentistry, allowing more precise diagnosis by professionals, simulation and surgical planning, previous adaptation of biomaterials and orthoses, as well as interaction between the surgeon and the patient, thus obtaining more satisfactory aesthetic results and decreased surgical time.
\end{abstract}

Indexing terms: Delivery of Health Care. Dentistry. Three-dimensional printing.

\section{RESUMO}

A utilização da prototipagem rápida na área médico-odontológica consiste na obtenção de modelos tridimensionais através de sistemas Computer Aided Design (CAD) e Computer Aided Manufacturing (CAM). Tais sistemas incidem especificamente sobre ferramentas de visualização aprimoradas 3D, que fornecem ao profissional a oportunidade de planejamento pré-operatório preciso através da impressão tridimensional. O objetivo deste trabalho é descrever as principais etapas na fabricação de biomodelos utilizando uma impressora 3D Objet (CONNEX 350), cuja matéria prima é uma resina fotopolimerizável. As etapas descritas são adotadas pelos pesquisadores do Laboratório de Tecnologias Tridimensionais (LT3D) do Núcleo de Tecnologias Estratégicas em Saúde, da Universidade Estadual da Paraíba, e iniciam-se com a aquisição das imagens tomográficas que são processadas por meio do softwares específicos e exportadas para o formato Stereolitography (STL). A técnica de manufatura aditiva utilizada é a estereolitografia, que consiste na construção do biomodelo por fotopolimerização de uma resina epoxy líquida usando radiação ultravioleta. O biomodelo resultante deste processo é levado à máquina pressurizadora para remoção da resina de suporte através de lavagem por jatos de água. Após esta etapa o mesmo é enviado ao profissional de saúde responsável. O uso de biomodelos constitui um grande avanço para a área da Odontologia, permitindo a realização de diagnósticos mais precisos por parte do profissional; simulação e planejamento cirúrgico; adaptação prévia de biomateriais e órteses; bem como a comunicação entre o cirurgião e o paciente, obtendo assim, resultados estéticos mais satisfatórios e diminuição do tempo cirúrgico.

Termos de indexação: Assistência à saúde. Odontologia. Impressão tridimensional.

\section{INTRODUCTION}

The growing search for excellence in the diagnosis and treatment of human body disorders has been a challenge for health professionals. The use of three-dimensional physical model (3D) which uses the data processing from Computer Aided Design (CAD) and Computer Aided Manufacturing (CAM) for the manufacture of high precision biomodels has been highlighted especially in the medical and dental fields ${ }^{1-3}$. The development of systems such as CAD and CAM fits the needs of surgeons and they result in a range of computing resources that help assisted surgeries. These systems focus specifically on the enhanced 3D visualization tools that provide accurate professional preoperative planning through the three-dimensional impression made by the

\footnotetext{
${ }^{1}$ Universidade Estadual da Paraíba, Faculdade de Odontologia. Rua Baraúnas, 351 Bairro Universitário, 58429-500, Campina Grande, PB, Brasil. Correspondência para / Correspondence to: AWP BARROS. E-mail: <waleskabarros2011@gmail.com>

${ }^{2}$ Universidade Estadual da Paraíba, Núcleo de Tecnologias Estratégicas em Saúde, Programa de Pós-Graduação em Ciência e Tecnologia em Saúde. Campina Grande, PB, Brasil.
} 
method of Additive Manufacturing (Rapid Prototyping). Advances in manufacturing technology and materials science has made possible that this virtual model or design to be used as models of physical replicas, surgical guides or intraoperative prostheses ${ }^{4-5}$.

The use of the three-dimensional prototypes, known in health as biomodels has enabled the surgeons to perform more accurate diagnosis and to visualize interesting surgical structures even before the surgery. The advantages for the patients are as follows: better aesthetics, reduced operative time and consequently anesthetic dose effects besides reduced exposure to causative agents of hospital infections ${ }^{6-8}$. Therefore, it is necessary to follow a sequence of steps that begin with the acquisition of the patient's radiographic images followed by additional diagnostic imaging, such as MRI (Magnetic Resonance Imaging), CTA Computed (Computed Axial Tomography) or CVT (Computed Volumetric Tomography), and its CAD conversion, thus achieving a 3D image of the object to be reproduced ${ }^{9-10}$. The subsequent steps consist of storage and transfer of image files to InVesalius software used for handling and converting them, and finally, in biomodel printing.

The steps presented here are those adopted by the researchers of the Three- Dimensional Technology Laboratory (3DTL) based on the Strategic Technologies Center for Health (NUTES), of the State University of Paraíba (UEPB), Brazil. NUTES is a reference center for the development of health technologies presenting biomedical engineering laboratories, electronics, software development and validation, and it is the only center of additive manufacture and manipulation of images, based in universities in the Brazilian Northeast.

It aims to describe the main steps in the production of biomodels using an Objet 3D printer (CONNEX 350), whose raw material is a light-curing resin. This printer is able to manufacture biomodels by stereolithography which provides good dimensional accuracy, ranging between 0.5 and $0.1 \mathrm{~mm}$, allowing reliable patient's transferred measures as well as minimum discrepancy between the model and the anatomical structure ${ }^{11}$.

\section{Steps to medical image production}

Soon after the surgeon obtains the radiographic images of the area of interest they are sent to the 3DTL.

The storage of these images, typically from CT scans is most commonly accomplished by CD (Compact Disc) or DVD (Digital Versatile Disc), due to the high storage capacity that such devices provide, supporting great amount of data generated by a CT in digital imaging and communications in medicine (DICOM) format ${ }^{12}$. In some cases, the CTs are directly sent to the lab e-mail; however when the request comes from other cities or states, these CTs are sent through the post office.

After obtaining the images, their processing is of utmost importance in order to separate the area of interest and the bone density range, which will be used for the generation of the three-dimensional biomodel file. One of the software most commonly used by 3DTL researchers is InVesalius, developed at the Renato Archer Information Technology Center (ITC) ${ }^{13}$, Campinas, Brazil (Figure 1).

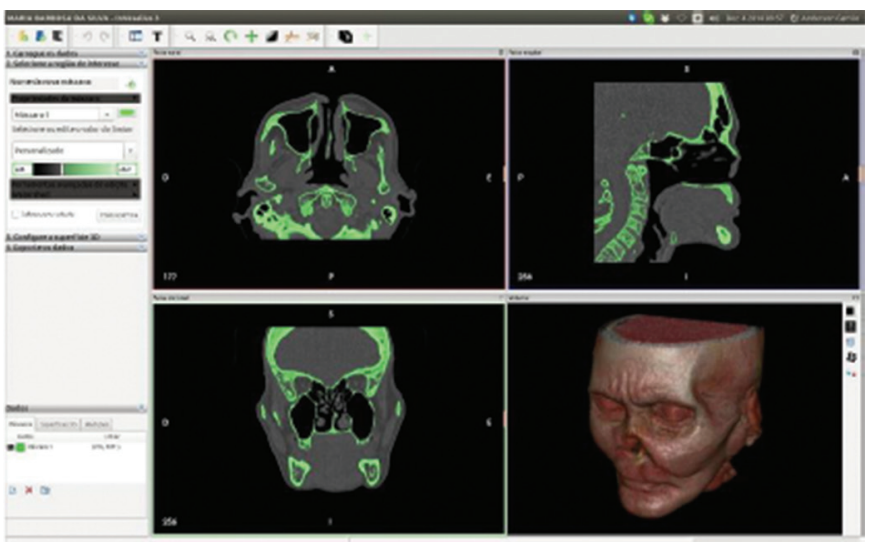

Figure 1. Visualization of the higher density areas indicated in green, using InVesalius software. Northeast of Brazil, in 2015.

The density must be limited in accordance to values compatible with bone structure, in order to avoid information loss which causes geometric errors in the final biomodel structure ${ }^{14-16}$. The InVesalius generates a file.stl which brings all the initial modeling made. In situations where there is still need for dimensional image improvement, a MeshLab ${ }^{\text {TM16 }}$ software, is used (Figure 2).

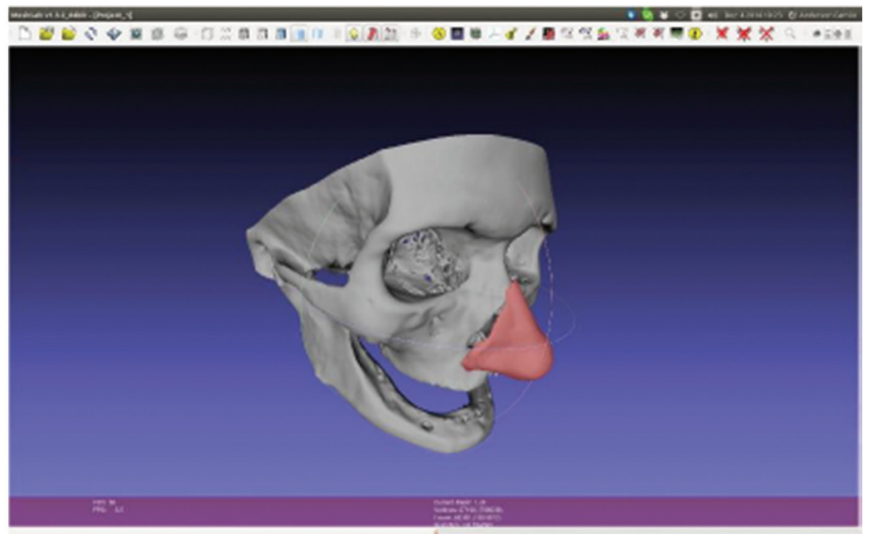

Figure 2. Using MashLab software in the modeling visualization for a nose reconstruction surgery planning. Northeast of Brazil, in 2015. 
The image processing is of crucial importance in order to reduce existing noise, a procedure performed on each of the patient's tomographic cuts (layer to layer). If necessary, the image can still be enhanced using other software which allow the division of the parts of the 3D polygonal mesh ${ }^{17-18}$.

The polygonal meshes are face collections which define a three-dimensional object. Typically, such surfaces are formed by triangles or quadrilaterals and may also present more complex geometrical shapes, depending on the application and the need observed for the treatment.

The image processing activity is extremely delicate since any great impact alteration on the file will compromise its original anatomy when it is printed in $3 \mathrm{D}$.

Afterwards the images are converted to Stereolithographic format (STL) which is the data pattern in most additive manufacturing technologies. Its geometry is represented by a mesh of triangular elements and their parameter files can generate meshes with larger or smaller triangles, influencing the softness of the resulting fabric. The Stereolithographic format (STL) is also used in 3DTL.

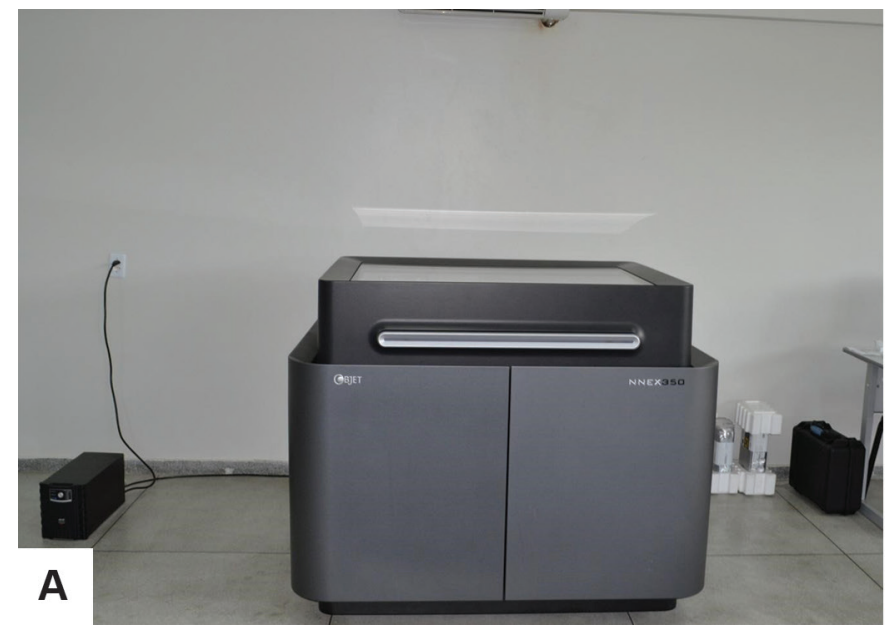

Figure 3. Objet CONNEX 350 Print . Northeast Brazil, 2015.

The resulting biomodel of this process shows good accuracy and surface quality (Figure 4) and after the deposition of the resin or printing, they are taken to the pressurizing machine to remove the resin support by washing with water jets in order to remove all their filling material (Figure 5).

In brief, stereolithography has shown many benefits in the manufacture of bio models. Its high accuracy provides faithful anatomical models through which it

\section{Stages of additive manufacturing}

There are basically five different printing processes for obtaining biomodels as follows: stereolithography (STL); Layer Object Manufacture (LOM); Selective Laser Sintering (SLS); Three- dimensional printing (TDP) and Fused Deposition Molding (FDM), which if classified by the type of material used can be subdivided into liquid, solid and powder ${ }^{1-17}$.

In this manuscript, the printer used for the biomodel production is the Objet, CONNEX 350 model (Figures $3 a$ and $3 b$ ) and the methodogy used is the Stereolithography, in which the biomodel is constructed on a $30 \mathrm{~cm}$ square platform, on both sides by curing a liquid epoxy resin, using ultraviolet radiation. This ultraviolet laser selectively polymerizes layer by layer the photocurable liquid of epoxy-based resin or acrylic. After the first layer is cured, the platform is submerged to a depth equivalent to the thickness of the layer corresponding to the $z$ axis; this allows the polymerized resin to cover the last layer. The process is repeated several times until the final biomodel is completely constructed.

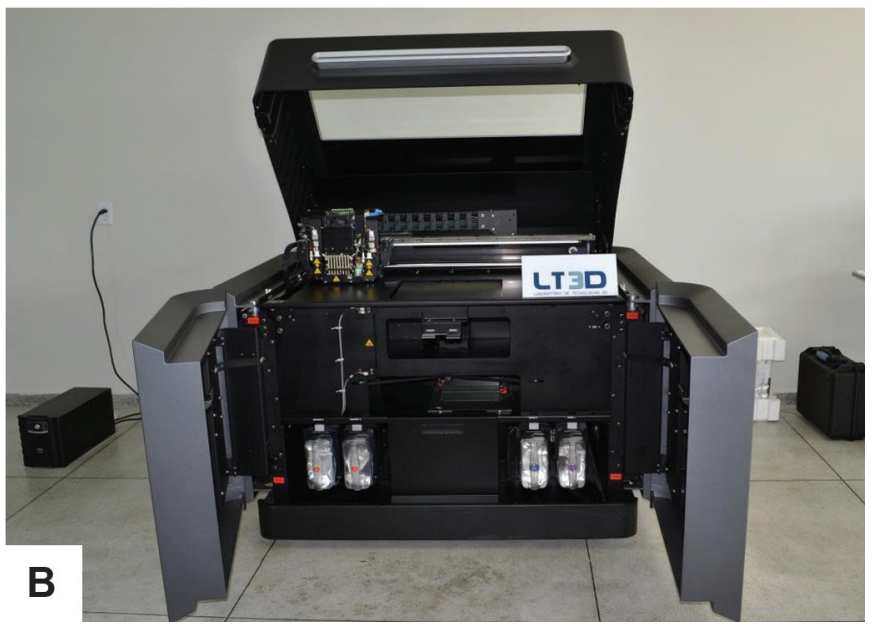

becomes possible to perceive tactile and visual structures of the anatomical and pathological regions studied. Thus, the biomodels are a major breakthrough for the medical and dental field, providing the professionals with more accurate diagnoses, simulation and surgical planning, previous adaptation of biomaterials and orthotics and also surgeon-patient interaction. All these features together result in more satisfactory aesthetic outcomes, reduced surgical time and anesthetic doses, as well. 


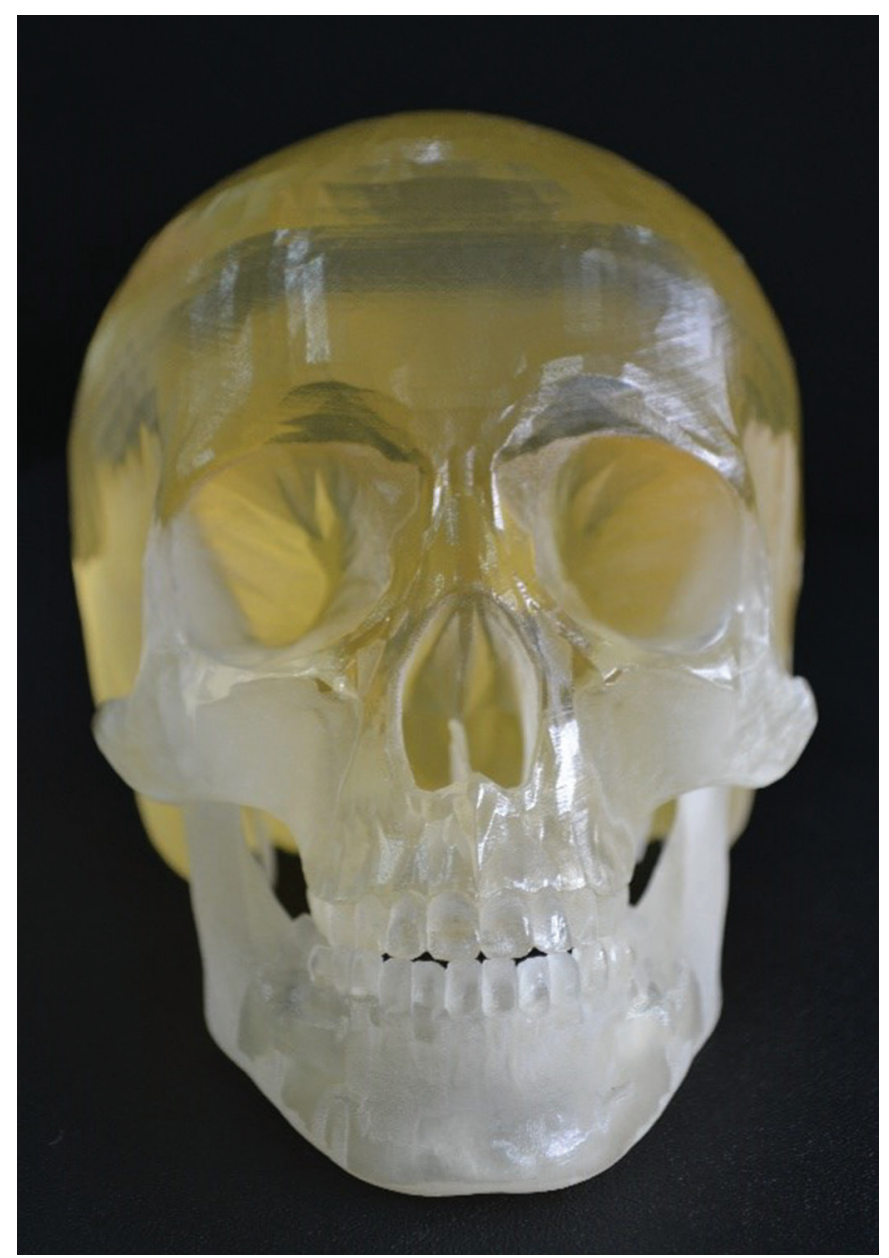

Figure 4. Skull biomodel. Northeast of Brazil, in 2015. 2015.

\section{Collaborators}

AWP BARROS and EPORTO participated in the writing of the manuscript. JFS LIMA participated in the

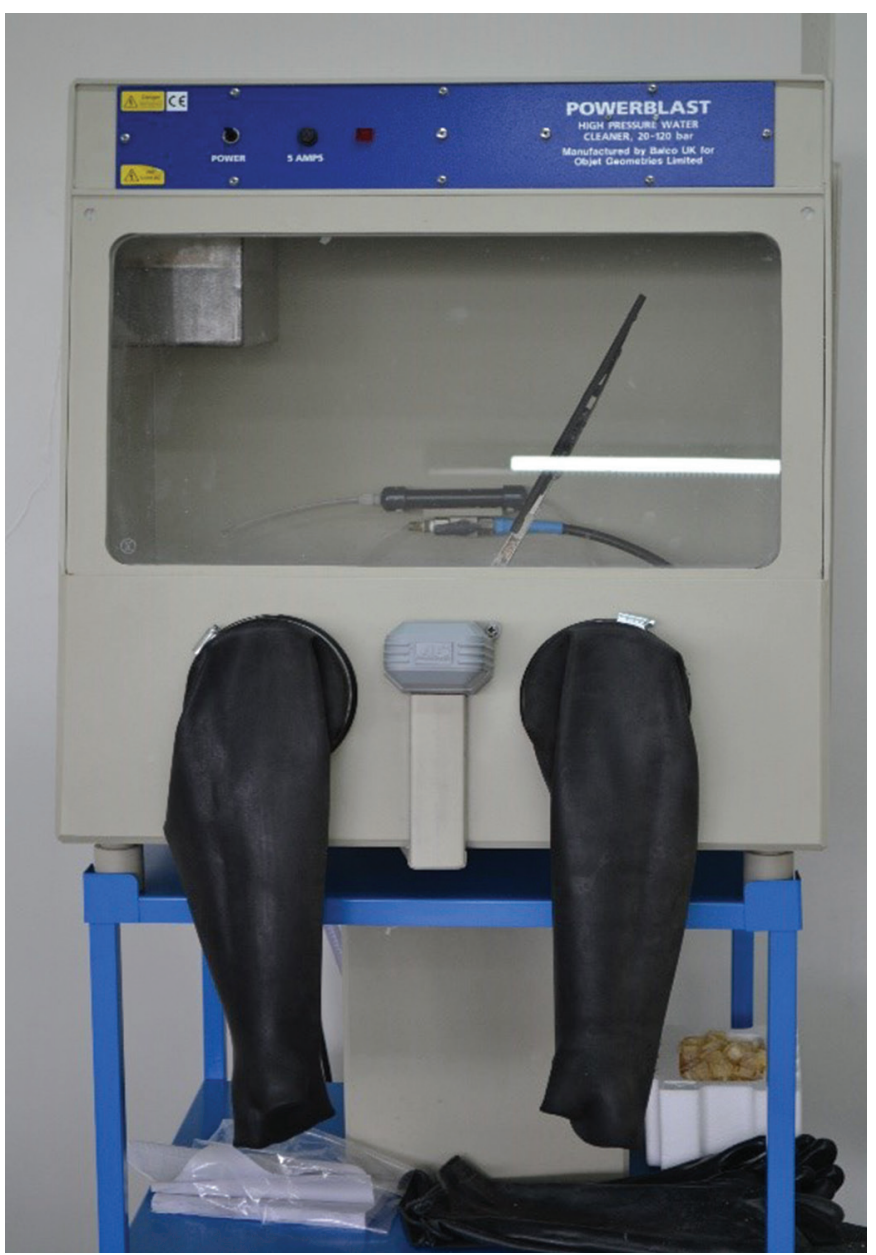

Figure 5. Water pressurizing Machine. Northeast of Brazil, in 2015.

drafting of detailed steps for medical images processing. NMSOL BRITO participated in the design, organization and writing of the article. SOARES RSC was responsible for critical review and writing of the article.

\section{REFERENCES}

1. Lino FJ, Neto R. A prototipagem rápida na indústria cerâmica, comparação com outros sectores industriais. Rev Kéramica. 2003;28(260):14-28.

2. Miyazaki T, Hotta Y, Kunii J, Kuriyama S, Tamaki Y. A review of dental CAD/CAM: current status and future perspectives from 20 years of experience. Dent Mater J. 2009 Jan;28(1):44-56. doi: $10.4012 / \mathrm{dmj} .28 .44$

3. Freitas SAP, Costa PM, Ribeiro RC. Uso de prototipagem biomédica em odontologia. Odontol Clín Cient. 2010 jul-set;9(3):223-7.

4. Parthasarathy J. 3D modeling, custom implants and its future perspectives in craniofacial surgery. Rev Maxillofac Surg. 2014;4(1):9-18. doi: 10.4103/2231-0746.133065

5. Li WZ, Zhang MC, Li SP, Zhang LT, Huang Y. Application of computer-aided three dimensional skull model with rapid prototyping technique in repair of zygomatico-orbito-maxillary complex fracture. Int J Med Robot. 2009;5(2):158-63. doi: $10.1002 /$ rcs. 242

6. Coser RC, Costa RC, Silva DF, Ritto FG, Alfaya TA, Gouvêa CVD R. C., et al. Use of Stereolithographic Models in the Surgical Planning of Maxillomandibular Odontogenic Tumors. Med Sci Tech. 2014;55:37-40. doi: 10.12659/MST.890381 
7. Eppley BL, Kilgo M, Coleman JJ. Cranial reconstruction with computer-generated hard-tissue replacement patient-matched implants: indications, surgical technique, and long-term followup. Plast Reconstr Surg. 2002 Mar;109(3):864-71.

8. Silva JVL, Gouvêia MF, Santa Barbara A, Meurer E, Zavaglia CAC. Rapid prototyping applications in the treatment of craniomaxillofacial deformities - utilization of bioceramics. Key Engin Mater. 2004;(254-256):687-90. doi: 10.4028/www. scientific.net/KEM.254-256.687

9. Dvorak P. Rapid Prototyping a Kidney and More [online]. USA: Medical Design Magazine; 2006 [cited 2016 set 20]. Available from: http://medicaldesign.com/prototyping/rapid-prototypingkidney-and-more

10. Fogiatto JA. O uso da prototipagem rápida na área médico odontológica. Tecnol Humanismo. 2006;20(30):60-8.

11. Kragskov J, Sindet-Pedersen S, Gyldensted C, Jensen KL. A comparison of three - dimensional computed tomography scans and stereolithographic models for evaluation of craniofacial anomalies. J Oral Maxillofac Surg. 1996;54(4):402-11. doi: 10.1016/S0278-2391(96)90109-3

12. DICOM Standards Committee. DICOM Home Page [cited 2015 Jul 2]. Available from: <http://medical.nema.org>.

13. Centro de Tecnologia de Informação Renato Archer. InVesalius - Software público de imagens médicas. [citado 2015 Jul 2]. Disponível em: <http://svn.softwarepublico.gov.br>.

14. Choi JY, Choi JH, Kim NK, Kim Y, Lee JK, Kim MK, et al. Analysis of errors in medical rapid prototyping models. Int J Oral Maxillofac Surg. 2002 Feb;31(1):23-32. doi: 10.1054/ijom.2000.0135
15. Kouhi E, Masood S, Morsi Y. Design and fabrication of reconstructive mandibular models using fused deposition modeling. Assembly Automat. 2008;28(3):246-54. doi: 10.1108/01445150810889501

16. Winder J, Bibb R. Medical rapid prototyping technologies: state of the art and current limitations for application in oral and maxillofacial surgery. J Oral Maxillofac Surg. 2005;63(7):1006-15.

17. Instituto di Scienza e Tecnologie dell'Informazione "A. Faedo". MeshLab - Software de imagens tridimensionais [citado 2015 Jul 2]. Disponível em: <http://meshlab.sourceforge.net>.

18. Azari A, Nikzad S. The evolution of rapid prototyping in dentistry: a review. Rapid Prototyping J. 2009 May;15(3):216-25. doi: $10.1108 / 13552540910961946$

19. Sinn DP, Cillo JE, JR Milles BA. Stereolithography for craniofacial surgery. J Craniofac Surg. 2006;17(5):869-75. doi: 10.1097/01. scs.0000230618.95012.1d

20. Hill Junior FS. Computer graphics using opengl. $2^{\text {a }}$ ed. USA: Prentice Hall; 2001. 